\title{
THE GENETICS OF TRANSFERRINS IN CATTLE
}

\author{
ALAN JAMIESON \\ A.R.C. Animal Breeding Research Organisation, Edinburgh, 9
}

Received 8.ii.65

\section{INTRODUCTION}

THE blood sera of animals contain distinct varieties of proteins which can be separated by electrophoretic methods. Certain serum protein systems show genetic variation within species. In this paper, genetic variation is described in the cattle beta globulin fraction, now often referred to as the transferrin or Tf system.

Species differ in the number of postulated genes at the Tf locus. The numbers range from one to sixteen known genes per species, and are limited by the number of samples and varieties of animals. studied. As far as is known, the European elk and the American bison each appear to be monomorphic with one transferrin gene (Braend, 1962; Stormont, 1964), but there is evidence for two transferrin genes. in mice, goats, kangaroos and poultry, three in pigs, six in horses, eight in cattle and reindeer, twelve in sheep and sixteen in man, who has been studied in greater numbers than any other species. (Ashton, 1958, 1959; Ashton and Ferguson, 1962; Ashton and Lampkin, 1965; Ashton and McDougal, r 958; Braend and Stormont, 1962, 1964; Cohen and Shreffler, 1960, 1961; Cooper and Sharman, 1964; Millson and Pattison, 196r; Osterhoff, 1964; Parker and Bearn, 1961).

In different species, the $\mathrm{Tf}$ genes are responsible for characteristic numbers of protein bands. In primate sera, each $\mathrm{Tf}$ gene expresses one major and one minor protein band (Harris et al., 1958; Smithies and Walker, 1956; Beckman, 1963). In other species examined each $\mathrm{Tf}$ gene is responsible for a pattern of protein bands. In horses, reindeer, goats, mice and birds each Tf gene expresses two bands, while in pigs and kangaroos there are three bands per gene and in bison, elk and cattle there are four.

In each species the band components of patterns attributed to different transferrin genes show characteristic staining intensities. In cattle, for example, each $\mathrm{Tf}$ gene expresses four evenly spaced protein bands, of which the fastest stains lightly, the next stains moderately and the remaining two stain intensely (Ashton, 1959).

Five phenotypes were recognised in the earliest descriptions of cattle transferrins (Ashton, 1957; Hickman and Smithies, 1957) and a sixth phenotype was added later (Ashton, 1958). A series of three allelomorphic genes at one locus, giving three homozygote and three heterozygote types accounted for these six phenotypes. This system of classification was used routinely for parentage testing in Sweden and 
Denmark (Gahne, 1961; Brummerstedt-Hansen et al., 1962) and was repeated in Canada (Gall and Berg, I964). Most recently, a fourth allele has been recognised in European cattle (Kristjansson, 1962) and four further alleles have been found in Zebu and Afrikaner cattle (Ashton, 1959; Ashton and Lampkin, 1965; Osterhoff, 1964).

This paper presents evidence for ten transferrin phenotypes in cattle tested in Britain. A revision of the notation for cattle transferrins is proposed in order to include the new types and provide a genetic interpretation. The inheritance of cattle transferrins is demonstrated using family data and twin data.

\section{MATERIAL, METHOD AND NOTATION}

\section{(i) Material}

Serum samples were taken from related cattle in two experimental herds within this Organisation, and at artificial insemination centres of the Milk Marketing Board of England and Wales.

One herd combined equal proportions of Ayrshire, Friesian and Jersey genes in a cyclical mating experiment using semen from a wide variety of A.I. bulls. The bulls themselves yielded a limited amount of father-son family data

The other herd was devoted to a uniformity trial experiment involving monozygotic and dizygotic twins of Ayrshire, Friesian and miscellaneous breeds and crosses. As the twins had been used extensively in comparative studies, the zygosity diagnoses of the pairs were determined before their transferrins were tested.

\section{(ii) Apparatus}

The starch gel was held in a mould or tray made from $6 \mathrm{~mm}$. plate glass. The base was $28 \times 14 \mathrm{~cm}$; and the edges were two ends of $12 \mathrm{~cm}$. and two sides of $28 \mathrm{~cm}$. The edges were glued to the base by a simple starch paste which was easily released for cleaning at the end of the run. The tray was put in an oven at $70^{\circ}$ to $90^{\circ} \mathrm{C}$. for at least one hour to dry the glue and warm the glass so it was not cracked by the hot fluid starch.

The electrode vessels were simple plastic dishes $34 \times 18 \times 7 \mathrm{~cm}$, each containing one litre of buffer solution at $p \mathrm{H} 8.7$, made of $0.10 \mathrm{M}$ sodium hydroxide and $0.03 \mathrm{M}$ boric acid. The tanks were alternated between runs and their contents replaced after six runs. They were put on the bench side by side about $15 \mathrm{~cm}$. apart and the gap bridged by two glass trays. Connexion between the gel in the trays and the buffer in the vessels was made by six thicknesses of surgical bandage folded to a $15 \mathrm{~cm}$. square. These wicks were soaked in the buffer of the electrode vessels and laid over the end $3 \mathrm{~cm}$. of the gels. A $20 \mathrm{~cm}$. length of 16 SWG (about $1 \cdot 6 \mathrm{~mm}$.) stainless steel wire was used as electrode in each vessel.

A simple but effective cooling device, consisting of a single sheet of polythene, suspended in a horizontal wooden frame $30 \times 20 \mathrm{~cm}$. and containing about $50 \mathrm{ml}$. of water was put on the gel to absorb heat during the test runs.

\section{(iii) Method}

The method used was essentially that of electrophoresis of the serum samples in a slab of starch gel (Smithies, r955) using the discontinuous buffer system (Poulik, 1957). The quantities quoted were sufficient to prepare one block of starch gel $25 \mathrm{~cm} . \times 12 \mathrm{~cm} . \times 6 \mathrm{~mm}$. in which nine serum samples could be run. Twenty-five gm. starch-hydrolysed (Connaught Medical Research Laboratories, Toronto, Canada) was mixed in $250 \mathrm{ml}$. of Tris-citrate buffer at $p \mathrm{H} 7.6$ (0.01 $4 \mathrm{M}$ 
tris-(hydroxy-methyl)-amino-methane, and o.004 M citric acid (British Drug Houses Ltd., Poole, Dorset, England). This proportion was used for all batches of starch and no differences between them were detected.

The mixture was swirled by hand in a $1 \frac{1}{2}$ l. conical flask over a bunsen flame. With increasing temperature the viscosity first increased and then decreased as the temperature approached $90^{\circ} \mathrm{C}$. The liquid was cleared of gas bubbles by connecting the flask to a suction pump at about $70 \mathrm{~cm}$. $\mathrm{Hg}$ negative pressure for 15-20 seconds. For reproducibile results, practise and experience are essential at this stage of the process.

The hot liquid was immediately poured into a glass tray as described above. A sheet of thin polythene was promptly rolled over the surface of the liquid excluding all air bubbles and a second glass plate, the size of the base plate, was put on top. Wrinkles in the polythene sheet were eliminated by pulling the protruding edges of the sheet. A $3 \mathrm{~kg}$. weight was laid on the top glass and the mass left in the refrigerator for 3 hours at about $4^{\circ} \mathrm{C}$. to set.

All serum samples used were stored at approximately minus $15^{\circ} \mathrm{C}$. in amounts up to about $5 \mathrm{ml}$. They were thawed in a $56^{\circ} \mathrm{C}$. water bath and returned to the freezer as soon as practicable after use. Some samples had been in store for 6 years before testing for this study while others were tested within a few days of bleeding. Sera which had been frozen and thawed 5 or 6 times gave weakly staining electrophoretic patterns, and samples which were frequently used, such as the reference sera, were stored in small volume aliquot parts so that each was thawed and refrozen no more than three or four times.

Of the nine serum samples inserted along each gel, the second, fifth and eighth were reference sera of established types, and the remaining six were sera under test. Fresh sera showing the recently established transferrin patterns $\mathrm{Tf}-\mathrm{d} \mathrm{I}$ and Tf-d2 were used extensively to allow the recognition of the minor differences between those patterns which could not be distinguished when matched against Tf-aze reference sera. See plate I.

Nine oblong pieces $10 \times 5 \mathrm{~mm}$. of Whatman No. I f filter paper were almost soaked in the serum samples to be tested, and inserted by forceps at equal intervals along a straight cut made into the starch by pressing in a knife almost as wide as the gel itself parallel to and $6 \mathrm{~cm}$. from the intended cathode end. The knife was removed, the gel covered with a polythene sheet and the current applied for I 5 minutes from a regulated direct current supply with an output of about 500 volts giving an average potential difference of about $\mathrm{I} 8$ volts per $\mathrm{cm}$. of gel. The current was interrupted for about one minute to remove the paper inserts, the edges of the cut gel were gently pressed together to remove all obvious air bubbles and the current reconnected.

The advancing " brown line" associated with the leading edge of the migrating borate ions indicate the rate of electrophoresis; after almost two hours, when it reached $10.5 \mathrm{~cm}$. beyong the line of the original insertions, the current was switched off. The glass sides were removed from the mould, surplus gel cut away and the sides were replaced by perspex strips $3 \mathrm{~mm}$. thick. Using these as depth guides, the gel was sliced in half horizontally by a stainless steel wire (gauge $3^{8}$ ) held taut between artery forceps. The top half of the gel was discarded and the bottom half sliced free of its supporting glass plate. An identifying number was painted on a corner of each gel using hæmoglobin solution on a fine brush.

The gel was immersed for 2 minutes in a dish containing I per cent. nigrosin (Gurr) in a solution of I volume glacial acetic acid, 7.5 volumes methyl alcohol and 5 volumes tap water. The stained gel was briefly rinsed in tap water and left overnight in a washing solution of 1 volume glacial acetic acid, 5 volumes methyl alcohol and 5 volumes water. One or two changes of this solution were made when necessary until the background gel was light blue and the stained protein components remained darkly stained. The gels were subsequently stored in tap water. 


\section{(iv) Notation}

The first descriptions of different phenotypes in the $\beta 2$-globulin fraction of cattle sera were made independently by Ashton (1957) and by Smithies and Hickman (1957). Their two systems did not correspond although both numbered the serum types I to $\mathrm{V}$. The earliest genotype descriptions used the locus symbol $\beta$ and agreed in part only. This symbol was replaced by $\mathrm{Tf}$ in several species because accumulating evidence indicated that all these particular globulins were transferrins and it was anticipated that the genetic mechanism controlling the variety of their expression, as well as their ability to bind iron, would be homologous in the different species (Giblett, 1959; Gahne, 1961). The only exception is in mice where the locus is called Trf to avoid confusion with the mutant tufted.

The existence of eight co-dominant allelomorphic genes at one locus provides the simplest genetical interpretation of at least twenty electrophoretic varieties now established, and up to sixteen postulated varieties. The latter are expected to occur rarely in some breeds of cattle, or as the predictable results of certain infrequent matings. Table I summarises past attempts to name these varieties and proposes a revised notation in which the eight alleles reported to date are written $T f^{a 1}, \mathrm{Tf}^{\mathrm{a}}$, $T \mathrm{Tf}^{\mathrm{b}}, \mathrm{Tf}^{\mathrm{d} 1}, \mathrm{Tf}^{\mathrm{d}}{ }^{2}, \mathrm{Tf}^{\mathrm{e}}, \mathrm{Tf}^{\mathfrak{l}}$ and $\mathrm{Tf} \mathrm{g}$. The thirty-six electrophoretic patterns they control are written genotypically as $\mathrm{Tf}^{\mathrm{a} 1} / \mathrm{Tf}^{\mathrm{a}}, \mathrm{Tf}^{\mathrm{a}} / \mathrm{Tf}^{\mathrm{a} 2}, \mathrm{Tf}^{\mathrm{a}} / \mathrm{Tf}^{\mathrm{b}}$ etc. and phenotypically as Tf-ai, Tf-atai2, Tf-aib, etc. The proposed phenotype symbols, which would be used most often, are in a straightforward style suitable for typewriting blood type certificates, or for printed outputs by most computers, where superscripts are not available. Although lower-case letters are preferred for naming multiple series of allelomorphic genes (Ogden et al., 1962), block letters do not introduce ambiguity. Letters previously used to define cattle transferrins are given priority in the proposed system, but the letter $\mathrm{O}$ (Smithies and Hickman, 1957) which implied an inert allele, is not adopted. The symbol $\mathrm{Tf}^{\alpha}{ }^{\alpha}$ with no numerical suffix represents two unspecified allelomorphic genes conferring transferrin patterns which show smaller differences than the others (Kristjansson, ig62). Where the technical methods allowed their distinction, it was found that both patterns occurred frequently in many breeds and to avoid ambiguity the symbol $\operatorname{Tf}^{\mathrm{d} 1}$ is proposed for the faster, and $\mathrm{Tf}^{\mathrm{d} z}$ for the slower. Similarly $\mathrm{Tf}^{\mathrm{a} 1}$ exceeds $\mathrm{Tf}^{\mathrm{a} z}$ in electrophoretic mobility. This use of letters and numbers is in close agreement with the established procedure of identifying human transferrins according to their electrophoretic mobility (Parker and Bearn, 1961).

Two of the genes recognised earlier, now called $T f^{a 2}$ and $T f^{e}$, plus the two new genes, $\mathrm{Tf}^{\mathrm{a} 1}$ and $\mathrm{Tf}^{\mathrm{a}}{ }^{2}$, are postulated to explain the genetic data in the results to follow. This paper gives the first genetic evidence for the genes $T f^{d 1}$ and $T f^{d a}$ segregating as co-dominant genes in the existing allelomorphic series. There is no data on the segregation of $\mathrm{Tf}^{\mathrm{d} 2}$ and $\mathrm{Tf}^{\mathrm{d} 2}$ in relation to the genes $\mathrm{Tf}^{\mathrm{a} 1}, \mathrm{Tf}^{\mathrm{b}}$, $\mathrm{Tf}^{\mathrm{t}}$ and Tfg.

\section{IDENTIFICATION}

After electrophoresis and staining, each haploid contribution to an observed cattle transferrin phenotype appears as a pattern of four bands. Each of these allelic patterns show three approximately equal intervals between their four bands. The corresponding bands in different allelic patterns show uniform staining intensities, in that the leading band stains faintly, the next moderately and the remaining two intensely. Visually, all the bands in homozygotes show twice the staining intensity as the same bands in heterozygotes.

The simple allelic patterns with four bands in each, are seen in the homozygotes. The genes are distinguished mainly by the relative mobilities of their complete patterns, and to a lesser extent by minor 
differences within their patterns. As the alleles are all co-dominant, each heterozygote gives the composite pattern expected by imposing the patterns of the two appropriate homozygotes. The ideal set of testing conditions would give the maximum resolution of the different proteins expressed by all the alleles in the system so that all heterozygotes would show eight bands, but in practice some over-lapping is unavoidable in some heterozygotes. Where the position of two bands coincide they appear darker but where two bands adjoined without overlapping, they appear as a broader band.

The eloctrophoretic patterns from eighteen sera were chosen to illustrate different transferrin types in plate $I$. The patterns are represented as a diagram in fig. I to emphasise small differences in the relative positions of the bands given under the conditions obtaining in the author's laboratory. Fig. I also contains information based on typing experience and shows some differences which were not always apparent. The samples are arranged in six sets of three, a heterozygous transferrin type, placed at the centre of each trio is flanked by its parental homozygous types. The second, fifth, eighth, eleventh, fourteenth and seventeenth samples are the six heterozygotes known in domestic cattle in Britain. In plate $I$ the first trio shows the heterozygote Tf-a2dI between the homozygotes Tf-a2 and Tf-dI and the second shows Tf-a2d2 between Tf-a2 and Tf-d2. The Tf-dI bands are slightly faster than the Tf-d2 bands, but matching either against $\mathrm{Tf}-\mathrm{a} 2$ did little to distinguish them. In the third trio, the heterozygote $\mathrm{Tf}$-a2e placed between $\mathrm{Tf}-\mathrm{a2}$ and $\mathrm{Tf}-\mathrm{e}$ shows the widest range of bands and the fourth trio Tf-dId2 between Tf-dI and $\mathrm{Tf}-\mathrm{d} 2$ shows the narrowest range of heterozygote pattern in cattle. With experience it is possible to discern the slightly greater mobilities of the Tf-dI bands compared with the Tf-d2. In the penultimate and last trio, the $\mathrm{Tf}-\mathrm{d}_{\mathrm{I}}$ and $\mathrm{Tf}-\mathrm{d}_{2}$ patterns are shown separately, and each combined with Tf-e. Tf-dre heterozygote showed certain small gaps between bands. Similar gaps did not appear in the corresponding positions of the Tf-dze heterozygote, the Tf-di bands having moved slightly faster than the corresponding Tf-d2 bands.

The transferrin genes $\mathrm{Tf}^{\mathrm{a}}, \mathrm{Tf}^{\mathrm{b}}, \mathrm{Tf}^{f}$ and $\mathrm{Tf}^{\mathrm{g}}$ were not represented in the material, but are stated to occur at the same genetic locus (Ashton, 1959; Ashton and Lampkin, I965; Osterhoff, 1964).

\section{RESULTS \\ (i) Family data}

The main evidence presented here on the inheritance of cattle transferrins is family data from an experimental herd in this organisation. This cyclical breeding experiment was based on Ayrshire, Friesian and Jersey cows inseminated using the semen of many bulls in the same three breeds. 
The family data were classified by the transferrin phenotypes of parents and offspring in table 2. Each of the 169 tested offspring

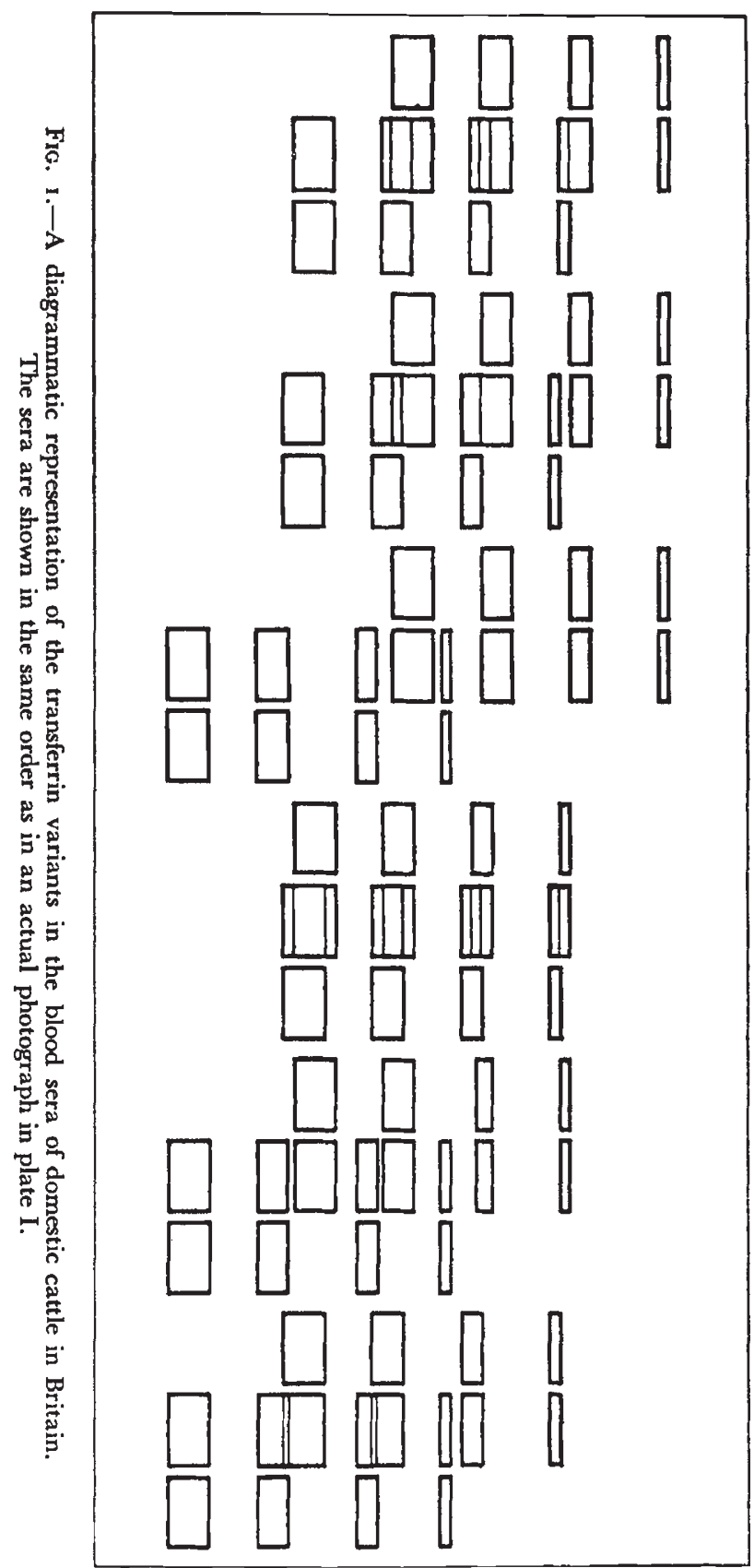

had both parents tested. As the available reciprocal matings produced similar progenies, the sex and breed of parents and offspring were not specified. After combining the reciprocals, the matings between all 
possible transferrin types were numbered $\mathrm{I}$ to 55 in the alphabetic order shown in table 3 so that the 35 which occurred had their progenies tabulated in rows. There were 167 single born female offspring. The numbers of calves per mating class varied from 0 to 18 , and involved almost as many parents of either sex, because the parents totalled 125 cows and 93 bulls.

The mating data in table 3 was satisfied by postulating four codominant genes $\operatorname{Tf}^{a 2}, \mathrm{Tf}^{\mathrm{d} 1}$, $\mathrm{Tf}^{\mathrm{d} 2}$ and $\mathrm{Tf} e$. The numbers of offspring by each mating were divided according to the simple segregations implied by this genetic model, and the expected numbers of calves, shown in brackets, were found to be in close aggreement with the observed numbers. All the 17 offspring of like homozygotes had their parents' transferrins, and all the I4 matings of unlike homozygotes produced the anticipated heterozygotes. All of the remaining matings were capable of showing segregations. They produced a total of 52 homozygotes where 54 were expected, and 86 homozygotes where 84 were expected. The observed and expected totals along the foot of table 3, do not suggest that any transferrin type was selected.

\section{(ii) Bulls and their sons}

A second source of information on the inheritance of cattle transferrins was data on 48 bulls and their 86 sons present at artificial insemination centres in Britain. The transferrin findings in fathers and sons are outlined in table 3 . The transferrins in the bulls' mothers were not known, but as Tf gene frequencies were estimated for breeds, the expected numbers of transferrin types in sons were computed, assuming one allelomorphic series of four $\mathrm{T} f$ genes, also assuming that their untyped dams were typical of their breeds. The observed numbers were in close agreement with the expected numbers.

The bull segregation data in table 3 supplement the earlier data which were limited to observations on heifer offspring, due to the early culling of bull calves born in dairy herds. The transferrins were inherited similarly by both sexes and no part of this data showed biased segregations of the kind observed earlier (Ashton, 1959).

\section{(iii) Transferrins in cattle twins}

Accounts of transferrins in 240 pairs of cattle twins appear in the literature. The genetical control of cattle transferrins was first suggested when 42 monozygotic twin cattle in the A.B.R.O. herd showed perfect agreement of transferrin types in pairs (Ashton, 1957). In tests on 92 twin pairs of mainly S.R.B. cattle, transferrin differences were seen within 29 of the 58 fraternal twin pairs (Gahne, r96r). In tests on 96 twin pairs of mainly Holstein-Friesian cattle, 24 of the 52 fraternal pairs showed different transferrins (Datta and Stone, 1963). Although all those quoted observations were restricted to six phenotypic classes, the present results suggest that ten phenotypes could have been recognised in the same material. 
A. JAMIESON

\begin{tabular}{|c|c|c|c|c|}
\hline & \multirow{11}{*}{ 密 } & \multirow{10}{*}{ 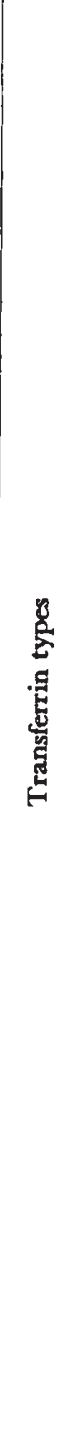 } & $\stackrel{\text { U }}{H}$ & 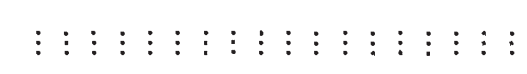 \\
\hline \multirow{12}{*}{ 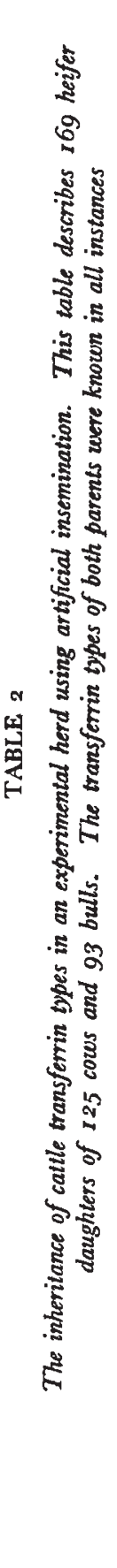 } & & & 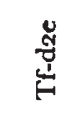 & $\vdots \vdots \vdots \vdots \vdots \vdots \vdots \vdots \vdots \vdots \vdots \vdots \vdots \vdots \vdots \frac{\widehat{N}}{\stackrel{n}{n}} \vdots \vdots$ \\
\hline & & & $\underset{⿱ 乛 龰}{*}$ & $\vdots \vdots \vdots \vdots \vdots \vdots \vdots \vdots \vdots \vdots \vdots \vdots \vdots \vdots: \frac{\widehat{m}}{\dot{m}} \vdots \vdots \stackrel{\widehat{m}}{m}$ \\
\hline & & & $\stackrel{0}{\stackrel{0}{⿱ 乛 龰}}$ & 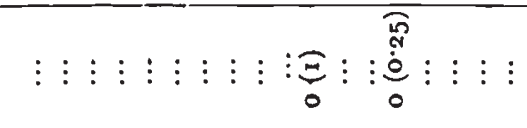 \\
\hline & & & 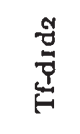 & 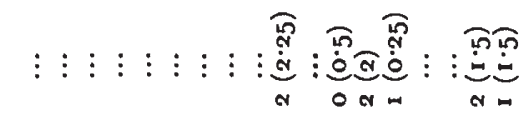 \\
\hline & & & $\underset{\underline{H}}{\bar{j}}$ & $\vdots \vdots \vdots \vdots \vdots \vdots \vdots \vdots \vdots \vdots \vdots \stackrel{\widehat{\varrho}}{0} \vdots \vdots \vdots \vdots \vdots \vdots$ \\
\hline & & & 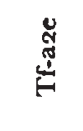 & 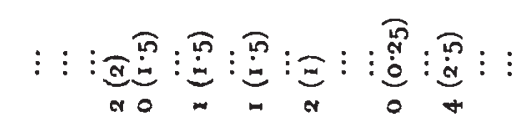 \\
\hline & & & 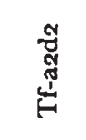 & 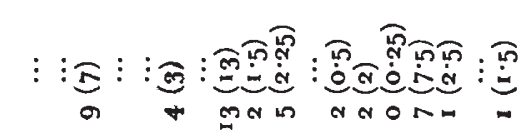 \\
\hline & & & $\underset{\overparen{H}}{\tilde{\sharp}}$ & : \\
\hline & & & 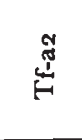 & 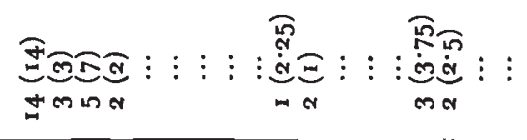 \\
\hline & & & : & 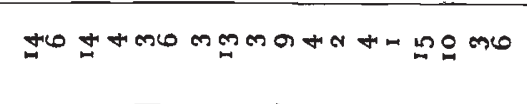 \\
\hline & & & 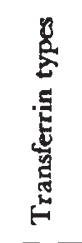 & 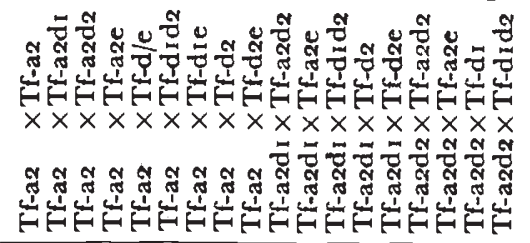 \\
\hline & & & 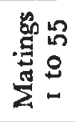 & - ๙ m the \\
\hline
\end{tabular}


TRANSFERRINS IN CATTLE

\begin{tabular}{|c|c|c|c|c|}
\hline \multirow{11}{*}{ 蜜 } & \multirow{10}{*}{ } & $\stackrel{U}{\mathscr{H}}$ & 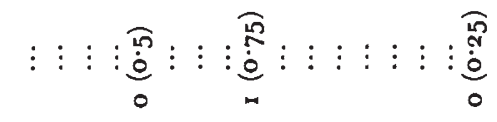 & $\stackrel{\widehat{n}}{\stackrel{0}{=}}$ \\
\hline & & 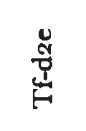 & 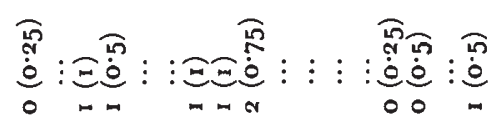 & $\begin{array}{c}\widehat{T} \\
\stackrel{4}{0} \\
0 \\
0\end{array}$ \\
\hline & & 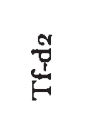 & 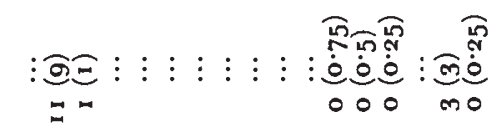 & $\frac{\widehat{\overparen{d}}}{\mathfrak{d}}$ \\
\hline & & 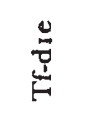 & 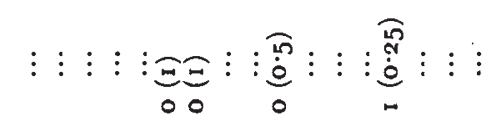 & $\underset{\varpi}{\Xi}$ \\
\hline & & 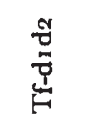 & 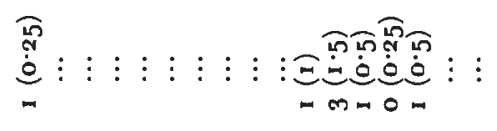 & $\underset{\mathscr{a}}{\stackrel{a}{\sim}}$ \\
\hline & & 虫 & 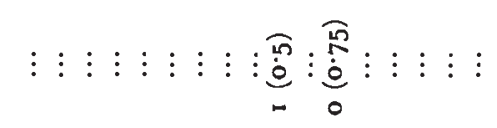 & $\stackrel{\substack{R \\
ٍ}}{2}$ \\
\hline & & 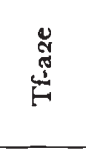 & 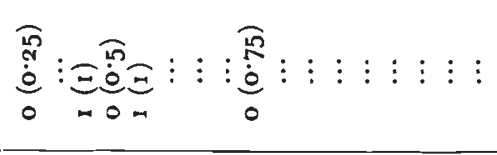 & 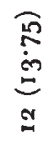 \\
\hline & & 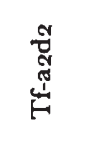 & : & 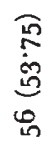 \\
\hline & & 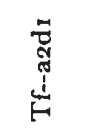 & 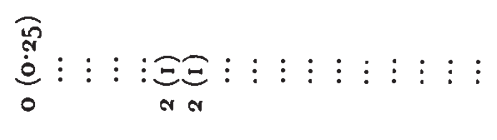 & 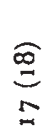 \\
\hline & & 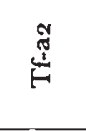 & $\vdots: \vdots: \stackrel{\widehat{0}}{0}: \vdots \vdots \vdots \vdots \vdots \vdots \vdots: \vdots \vdots \vdots \vdots$ & क्ले \\
\hline & & & $-\infty+\infty \pi+\alpha m-\infty \pi-\infty m$ & $\stackrel{\oplus}{\oplus}$ \\
\hline & & 递 & 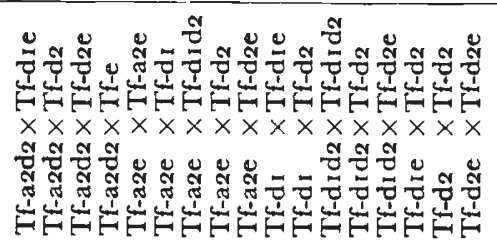 & 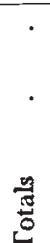 \\
\hline & & 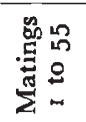 & 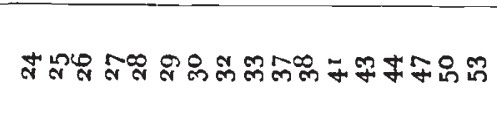 & \\
\hline
\end{tabular}


The transferrin types of 488 more twin cattle are presented in table 4 as family data containing no evidence of any non-genetic twinship effect. The twin totals in table 5 demonstrate the value of transferrin data in the zygosity diagnoses of cattle twins.

According to zygosity diagnoses made before the transferrins were tested, about half the pairs were believed to be monozygotic. Those identical twin cattle appeared in ten transferrin classes. No intra-pair difference was observed in any pair labelled monozygotic. The twins' parents were not tested, but the extended Hardy-Weinberg proportions in $\left(a_{2}+d \mathrm{I}+\mathrm{d} 2+\mathrm{e}\right)^{2}$ gave the expected numbers of transferrin types among 74 Ayrshires, 9 Friesian and 39 miscellaneous monozygotic

TABLE 3

Transferrins in bulls and their sons

\begin{tabular}{|c|c|c|}
\hline \multirow{2}{*}{$\begin{array}{l}\text { Sire transferrin } \\
\text { type }\end{array}$} & \multicolumn{2}{|c|}{ Son transferrin type } \\
\hline & Like sire & Not like sire \\
\hline $\begin{array}{l}\text { Tf-a2 } \\
\text { Tf-a2dI } \\
\text { Tf-d1 } \\
\text { Tf-a2d2 } \\
\text { Tf-dId2 } \\
\text { Tf-d2 } \\
\text { Tf-a2e }\end{array}$ & $\begin{array}{ll}7 & (6) \\
3 & (2) \\
3 & (2) \\
2 & (2) \\
2 & (5) \\
1 & (1) \\
1 & (3)\end{array}$ & $\begin{array}{lr}5 & (6) \\
4 & (5) \\
5 & (6) \\
4 & (4) \\
20 & (17) \\
2 & (2) \\
9 & (7)\end{array}$ \\
\hline Totals & $19 \quad(21)$ & $49 \quad(47)$ \\
\hline
\end{tabular}

Expected numbers in brackets.

twin pairs. The observed numbers of types of Ayrshire and Friesian monozygotic twin pairs showed close agreement with expectations in all ten types. The monozygotic pairs by miscellaneous breed crosses showed an excess of 5 heterozygous pairs.

The expected proportions of transferrin types in dizygotic twin members were computed using methods outlined in the final section of these results. The 6o Ayrshire and 32 Friesian dizygotic pairs were distributed about the possible genotype pair categories in table 4 in close agreement with the expected numbers shown in brackets. The less close agreement of crossbred twins is more apparent in the table 5 totals.

The transferrins invariably supported the monozygotic diagnoses of twins towards the top of table 5. The percentages in the final row of table 5 show how the tests for cattle transferrins confirmed the dizygosity of just over half of the purebred twin cattle and slightly fewer crossbred twins. The transferrin results for twins were condensed to show the observed and expected totals of twin pairs with known transferrins and zygosities. The observed and expected numbers are shown separately for the Ayrshire and Friesian twins. The remaining 
TABLE 4

Transferrins in monozygotic and dizygotic cattle twins

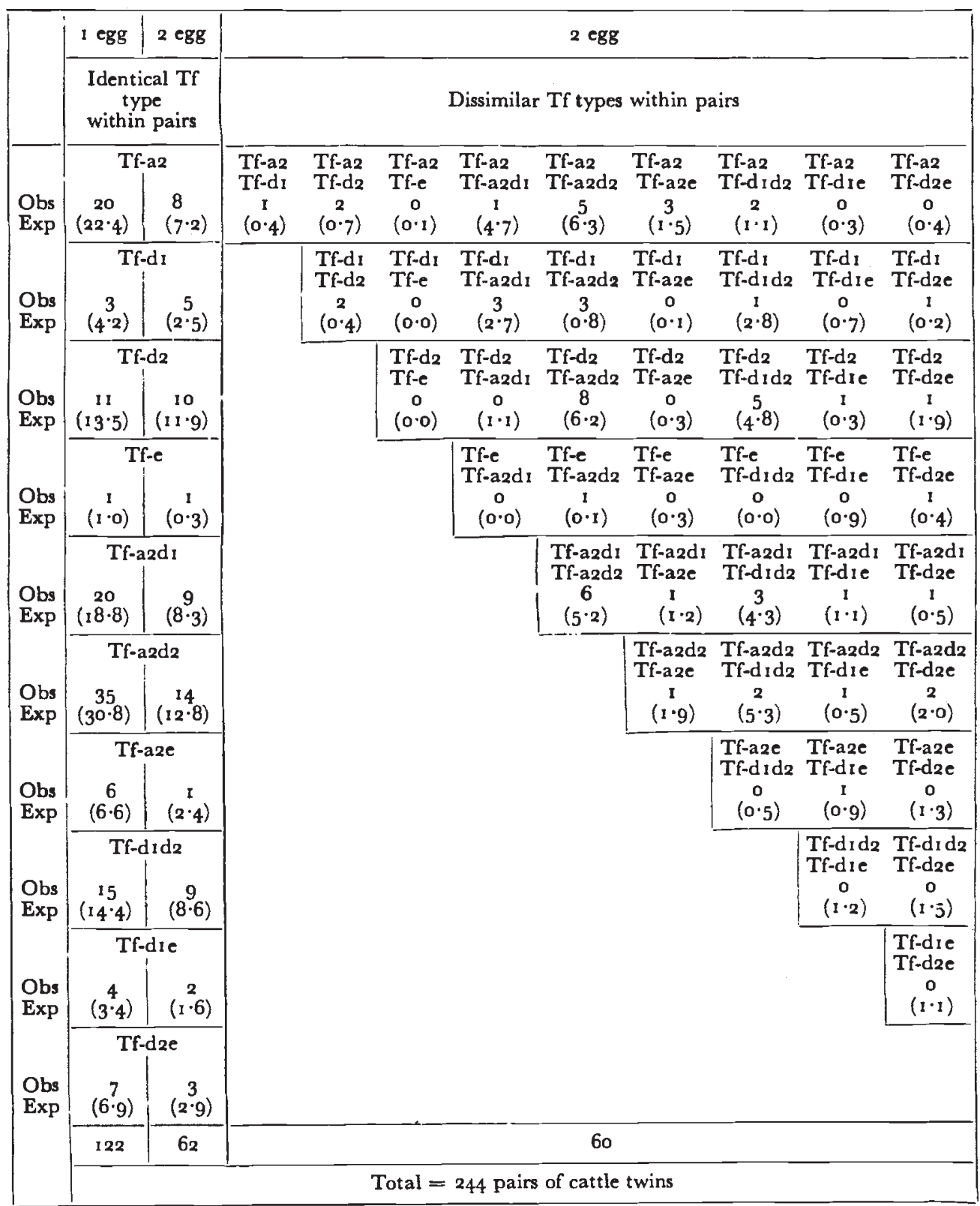

Ten transferrin types were observed in 488 twin cattle. The last part of this results section explains how ten phenotypes may form a maximum of 55 distinct pair combinations, including 10 with similar members, and 45 with different members. A detailed account of the transferrin types in 122 monozygotic twin pairs is shown in the first column of data and the next column details 62 dizygotic twins whose pair members also had identical transferrins. The 60 dizygotic twin pairs in which transferrin differences confirmed zygosity are shown within a triangular block. Of the 45 compartments in this triangle, 27 were occupied by from 1 to 8 pairs each, and 18 of the combinations of rarer transferrin types were not represented. The transferrin types of the twins' parents were not known, but the number of twin pairs expected in each pair category were calculated using the method outlined in the section devoted to probabilities. 
miscellaneous cattle twin pair totals had their expected proportions derived by combining the expectations in the breeds. The anticipated percentages, also shown in table 5 , were calculated using the $\mathrm{P}_{4}$ formula in table 8. The observed and expected purebred percentages showed close agreement. The disproportion among the crossbred twins was biased in favour of pairs of like heterozygotes. The same was seen among the monozygotic crossbreds. This is not surprising

TABLE 5

The data already shown in table 4 was summarised to compare the transferrins in cattle twins under breeds

\begin{tabular}{|c|c|c|c|c|c|c|c|c|c|}
\hline \multirow{3}{*}{$\begin{array}{l}\text { Twin } \\
\text { zygosity }\end{array}$} & \multirow{2}{*}{\multicolumn{2}{|c|}{$\begin{array}{l}\text { Combinations of trans- } \\
\text { ferrins in twin members }\end{array}$}} & \multicolumn{6}{|c|}{ Breeds and breed crosses } & \multirow{3}{*}{$\begin{array}{l}\text { Total } \\
\text { pairs }\end{array}$} \\
\hline & & & \multicolumn{2}{|c|}{ Ayrshire } & \multicolumn{2}{|c|}{ Friesian } & \multicolumn{2}{|c|}{ Crossbreds } & \\
\hline & Classes & Description & obs. & $\exp$. & obs. & exp. & obs. & exp. & \\
\hline \multirow[t]{2}{*}{ I egg } & \multirow[t]{2}{*}{$\begin{array}{l}4 \\
6\end{array}$} & \multirow[t]{2}{*}{$\begin{array}{l}\text { Like homozygotes } \\
\text { Like heterozygotes }\end{array}$} & $\begin{array}{l}20 \\
54\end{array}$ & \multirow[t]{2}{*}{$\begin{array}{l}20 \\
52\end{array}$} & $\begin{array}{l}5 \\
4\end{array}$ & & $\begin{array}{l}10 \\
29\end{array}$ & \multirow[t]{2}{*}{$\begin{array}{l}15 \\
25\end{array}$} & \\
\hline & & & 74 & & 9 & & 39 & & 122 \\
\hline \multirow[t]{4}{*}{2 eggs } & \multirow[t]{2}{*}{$\begin{array}{l}4 \\
6\end{array}$} & \multirow[t]{2}{*}{$\begin{array}{l}\text { Like homozygotes } \\
\text { Like heterozygotes }\end{array}$} & $\begin{array}{l}10 \\
19\end{array}$ & \multirow[t]{2}{*}{$\begin{array}{r}8 \\
18\end{array}$} & $\begin{array}{l}9 \\
5\end{array}$ & \multirow[t]{2}{*}{$\begin{array}{l}5 \\
9\end{array}$} & $\begin{array}{r}5 \\
14\end{array}$ & \multirow[t]{2}{*}{$\begin{array}{l}4 \\
9\end{array}$} & \\
\hline & & & 29 & & 14 & & 19 & & 62 \\
\hline & 45 & $\begin{array}{l}\text { Dissimilar pairs of } \\
\text { all types }\end{array}$ & $3^{1}$ & 34 & 18 & 17 & 11 & 17 & 60 \\
\hline & \multicolumn{2}{|c|}{$\begin{array}{c}\text { dissimilar dizygotic } \times \text { I } 00 \\
\text { total dizygotic }\end{array}$} & $\begin{array}{l}52 \\
\text { per cent. }\end{array}$ & $\begin{array}{l}57 \\
\text { per cent. }\end{array}$ & $\begin{array}{c}56 \\
\text { per cent. }\end{array}$ & $\begin{array}{l}54 \\
\text { per cent. }\end{array}$ & $\begin{array}{c}37 \\
\text { per cent. }\end{array}$ & $\begin{array}{c}55 \\
\text { per cent. }\end{array}$ & 244 \\
\hline
\end{tabular}

as the crossbreds were of varied origin, their expectations were based on Ayrshire and Friesian data and the products of crosses between genetically distinct breeds may be expected to be more uniformly heterozygous.

\section{(iv) No transferrin chimera was found}

The placental blood vessels of twin calf embryos usually anastomose in utero, and the twins interchange some erythropoietic cells. About go per cent. or more of dizygotic twin cattle of all ages are known to contain two populations of erythrocytes, one formed by the host, and the other formed by tissues accepted earlier from the co-twin. Because the foreign erythrocytes persist throughout the life of their host, they may be regarded as the products of a tolerated tissue graft. Such twin cattle are said to contain erythrocyte mosaicism and are often called red cell chimeras. 
Any set of circumstances permitting transferrin chimeras in twins would be about as probable as the conditions which permit erythrocyte (Owen, 1945) and leucocyte (Booth et al., 1957) chimeras. Transferrin chimeras would result if twin embryos interchanged cells which differentiated to synthesise genotypically foreign transferrins tolerated in their host. There is no obvious reason why chimeras should be restricted to blood cells, but no definite evidence for their extension to other tissues.

The cattle twin transferrin chimeras, if they did exist, would presumably cause an apparent reduction in those intra-pair transferrin differences due to segregating Tf genes. Some of the mixed transferrin types would falsely appear to be heterozygotes, others would appear as if they were triploid, and an apparent tetraploid transferrin type would be the ultimate, if the mixture contained transferrins from dissimilar heterozygous sibs, by parents containing four Tf genes. The occurrence of the supposed chimeras would reduce differences between pair members. In addition their appearance would be confused by the proportions, and by the gene dosages, of the transferrins from both sources.

Transferrin chimeras were postulated to explain the transferrins in four pairs of dizygotic twin cattle at Wisconsin, U.S.A. (Datta and Stone, 1963). The expectations of transferrins in dizygotic twins in table 4, would have been equally applicable to single born full sibs, as no allowance was made for transferrin chimeras. The value of this negative evidence was considered against a chimerical model in table 6.

Models can be made showing any incidence of chimeras. The imagined effect of a universal chimerical model in table 6 destroys all differences between twin members. The numerical examples in table 6 are based on the twin data in table 4. The uninformative twins with genotypically identical members not obviously changed as chimeras, are shown in the left half of table 6. Twins shown on the right contain different transferrin genotypes, but the formation of chimeras causes one or both members of each pair to gain alien transferrins produced by a co-twin. As a result of this supposed mixing, the 4 homozygous transferrin phenotypes are not apparent. and 5 new transferrin phenotypes are created.

Transferrin chimeras were not evident in the twins, because the observed numbers of transferrin types in dizygotic pairs agreed well in table 4 with the numbers expected if chimeras did not occur. In general, there was no deficiency in the number of dizygotic twins showing transferrin differences. In particular, there was no reduction in the proportion of dizygotic twins in which one member was a homozygote, and no twin showed transferrins appropriate to more than two transferrin genes. The latter category is the most critical, because one unusual observation would have been sufficient to establish a transferrin chimera. The sample contained 54 opportunities for 
possible chimeras to show themselves in this way, provided by the 27 pairs in rows I I to 15 in table 6.

But for eight exceptional results, the quoted and reported cattle twin data gave no indication of transferrin chimeras. The exceptions were 8 Tf-a2d cattle forming 4 dizygotic twin pairs (Datta and Stone,

TABLE 6

A chimerical model

\begin{tabular}{|c|c|c|c|c|c|}
\hline & \multicolumn{5}{|c|}{ The supposed appearance of transferrin chimeras in the twins } \\
\hline & \multicolumn{2}{|c|}{ No change } & \multicolumn{2}{|c|}{ Change } & \multirow{3}{*}{ Totals } \\
\hline & \multicolumn{2}{|c|}{$\begin{array}{l}\text { The monozygotic and dizygotic } \\
\text { pairs with identical transferrins } \\
\text { would remain unchanged }\end{array}$} & \multicolumn{2}{|c|}{$\begin{array}{l}\text { The different transferrins in } \\
\text { some dizygotic twin pairs would } \\
\text { coalesce to appear as pairs with } \\
\text { similar members }\end{array}$} & \\
\hline & Phenotype & Pairs & Pseudo-type & Pairs & \\
\hline $\begin{array}{l}1 \\
2 \\
3 \\
4\end{array}$ & $\begin{array}{l}\text { Tf-a2 } \\
\text { Tf-di } \\
\text { Tf-dz } \\
\text { Tf-e }\end{array}$ & $\begin{array}{r}28 \\
8 \\
21 \\
2\end{array}$ & \multicolumn{2}{|c|}{ No homozygote apparent } & $\begin{array}{r}28 \\
8 \\
21 \\
2\end{array}$ \\
\hline $\begin{array}{r}5 \\
6 \\
7 \\
8 \\
9 \\
10\end{array}$ & $\begin{array}{l}\text { Tf-a2d } 1 \\
\text { Tf-a2d2 } \\
\text { Tf-aze } \\
\text { Tf-didz } \\
\text { Tf-die } \\
\text { Tf-dze }\end{array}$ & $\begin{array}{r}29 \\
49 \\
7 \\
24 \\
6 \\
10\end{array}$ & \multirow{2}{*}{ 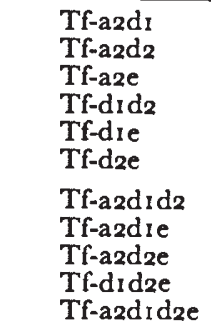 } & $\begin{array}{r}5 \\
15 \\
3 \\
8 \\
0 \\
2\end{array}$ & $\begin{array}{r}34 \\
64 \\
10 \\
32 \\
6 \\
12\end{array}$ \\
\hline $\begin{array}{l}11 \\
12 \\
13 \\
14 \\
15\end{array}$ & \multicolumn{2}{|c|}{$\begin{array}{l}\text { No animal showing more than } \\
\text { its own transferrins }\end{array}$} & & $\begin{array}{r}16 \\
3 \\
4 \\
2 \\
2\end{array}$ & $\begin{array}{r}16 \\
3 \\
4 \\
2 \\
2\end{array}$ \\
\hline & \multicolumn{2}{|c|}{$\begin{array}{l}122 \text { monozygotic } \\
+62 \text { dizygotic }=184 \text { pairs }\end{array}$} & \multicolumn{2}{|c|}{60 dizygotic pairs } & 244 pairs \\
\hline
\end{tabular}

This model describes the qualitative uniformity which would result within twin pair members if transferrin chimeras occurred throughout a sample of cattle twins genotypically equivalent to the twins in table 4.

1963). Datta and Stone did not distinguish the products of $\mathrm{Tf}^{\mathrm{d}} \mathbf{1}$ and $\mathrm{Tf}^{\mathrm{d} 2}$ genes, so it is possible that if their four pairs of $\mathrm{Tf}$-a2d cattle had been described in more detail, each pair would have one Tf-a2d I member and one Tf-a2d2 member. Differences which could be mistaken for chimeras, may be seen when comparing the second and fifth sera in plate I. Such pair combinations are not uncommon among cattle twins. Six pairs of $\mathrm{Tf}-\mathrm{a}_{2} \mathrm{~d} \mathrm{I}$ with $\mathrm{Tf}-\mathrm{a}_{2} \mathrm{~d}_{2}$ are reported here; they are expected to occur once in ten pairs of Friesian dizygotic twins.

This possible explanation of the reported chimeras is not consistent 
with the absence of similar variants among $5^{8}$ single born Tf-a2d cattle they described simultaneously.

Ten transferrin types were present in the family data in table 3 , and using the same testing technique, the same ten types accounted for all the transferrin variation in a diverse population of cattle in a survey of breeds in Britain (Jamieson in press). No additional transferrin type, or new mixture of known transferrins was seen in the twins. The twins showed examples of all ten types.

\section{(v) The probable occurrence of varieties}

The algebra in this section applies to allelomorphic series containing any number of co-dominant genes. The expressions describe the

TABLE 7

Seven possible classes of pairs

\begin{tabular}{|c|c|c|c|c|c|c|c|}
\hline \multirow{2}{*}{ Classes } & \multirow{2}{*}{ Possible pairs } & \multirow{2}{*}{$\begin{array}{l}\text { Alleles } \\
\text { common } \\
\text { to both }\end{array}$} & \multicolumn{4}{|c|}{$n$ value examples } & \multirow{2}{*}{$\begin{array}{c}\text { Number of possible } \\
\text { pairs }\end{array}$} \\
\hline & & & 3 & 4 & 5 & 6 & \\
\hline $\begin{array}{l}1 \\
2 \\
3 \\
4 \\
5 \\
6 \\
7\end{array}$ & $\begin{array}{l}\text { Like homozygotes } \\
\text { Like heterozygotes } \\
\text { Unlike homozygotes } \\
\text { Homozygote } \times \text { heterozygote } \\
\text { Homozygote } \times \text { heterozygote } \\
\text { Unlike heterozygotes } \\
\text { Unlike heterozygotes }\end{array}$ & $\begin{array}{l}\text { all } \\
\text { both } \\
\text { none } \\
\text { one } \\
\text { none } \\
\text { one } \\
\text { none }\end{array}$ & $\begin{array}{r}3 \\
3 \\
6 \\
18 \\
6 \\
6 \\
0\end{array}$ & $\begin{array}{r}4 \\
6 \\
12 \\
24 \\
24 \\
24 \\
6\end{array}$ & $\begin{array}{r}5 \\
10 \\
20 \\
40 \\
60 \\
60 \\
30\end{array}$ & $\begin{array}{r}6 \\
15 \\
30 \\
60 \\
120 \\
120 \\
90\end{array}$ & $\begin{array}{l}n \\
0 \cdot 5 n(n-1) \\
n(n-1) \\
2 n(n-1) \\
n(n-1)(n-2) \\
n(n-1)(n-2) \\
0.25 n-1)(n-2)(n-3)\end{array}$ \\
\hline & Total matings . & . & 36 & 100 & 225 & 441 & {$[n+0.5 n(n-1)]^{2}$} \\
\hline
\end{tabular}

possible numbers, varieties and frequencies of genes, genotypes, matings and segregants. The expressions also form a basis for the application of allelomorphic series to identify single animals (table Io), to diagnose the zygosity of twins (tables 4, 5, 8 and ro), and to investigate possible error rates in pedigrees (tables 9 and ro).

An allelomorphic series of $n$ genes gives $n+0 \cdot 5 n(n-1)$ genotypes, made up of $n$ homozygotes plus $0.5 n(n-1)$ heterozygotes, e.g. for series of $n=3$ to 7 genes the increasing numbers of possible genotypes are $6,10,15,21$ and 28 . There is a more rapid increase in the possible number of matings involving the available genotypes, and the appropriate formula is $[n+0.5 n(n-1)]^{2}$ giving 36 , I00, 222, 44I and 784 matings for $n=3$ to 7 genes. By omitting the reciprocal matings this series becomes 21, 55, 120, 231 and 406 matings.

It is useful to recognise the seven possible kinds of genotype pairs which are potentially present in all series exceeding three allelomorphic genes. The various pairs may appear as matings, interchanges or twins. All of the seven possible mating classes are shown in table 7 in which formulæ define the total numbers of distinct pairs in each 
class but do not give their frequencies. The probability of the random occurrence of any pair is simply the product of the frequencies of all four genes in the two genotypes. Other probabilities may be calculated for the occurrence of related pairs.

Assuming that all the genotypes were apparent, offspring of monogamous parents would contain I, 2, 3 or 4 genotypes at each locus, segregating as $\mathrm{I}, 0.5: 0.5,0.25: 0.5: 0.25$ and $0.25: 0.25: 0.25: 0.25$, to give twin diagnostic probabilities of $0.0,0.5,0.625$ and 0.75 respectively. The latter probability, which occurs only when the two parents contain four distinct allelomorphs, demonstrates the

TABLE 8

Formule defining the probability of genetic segregation occurring between the members of dizygotic twin pairs

\begin{tabular}{|c|c|}
\hline $\mathbf{P}_{1}$ & 0 \\
\hline $\mathbf{P}_{2}$ & $a b(2-1 \cdot 5 a b)$ \\
\hline$P_{3}$ & $\begin{array}{r}a b(2-a c-b c-1 \cdot 5 a b) \\
+a c(2-a b-b c-1 \cdot 5 a c) \\
+b c(2-a b-a c-1 \cdot 5 b c)\end{array}$ \\
\hline$P_{4}$ & $\begin{array}{r}a b(2-a c-b c-a d-b d-c d-1 \cdot 5 a b) \\
+a c(2-a b-b c-a d-b d-c d-1 \cdot 5 a c) \\
+b c(2-a b-a c-a d-b d-c d-1 \cdot 5 b c) \\
+a d(2-a b-a c-b c-b d-c d-1 \cdot 5 a d) \\
+b d(2-a b-a c-b c-a d-c d-1 \cdot 5 b d) \\
+c d(2-a b-a c-b c-a d-b d-1 \cdot 5 c d)\end{array}$ \\
\hline $\mathbf{P}_{n}$ & $\left.\sum_{i>i} p_{i} p_{j}\left[\left(2-0.5 p_{i} p_{j}\right)-\sum_{i>j} p_{i} p_{j}\right)\right]$ \\
\hline
\end{tabular}

maximum contribution of any one genetic locus towards establishing dizygosity in twins.

Monozygotic twins always belong to the first or second classes in table 7 but all seven genotype pair classes can occur in dizygotic twin pairs. The probability of any two genotypes occurring in a twin pair, not being a random occurrence, is restricted by their genetic relationship. To compute the expected proportions of genotypes in dizygotic twin pair members, it is necessary to consider all the parental matings, and the transferrins in all possible families containing two offspring. The probability of any pair of genotypes occurring together in dizygotic twins is obtained by adding the frequencies of the several ways in which the pair could arise. As only those twin pair members having dissimilar genotypes can establish dizygosity, the frequencies of all such pairs were summed to give the formulæ in table 8 .

The probability formulæ in table 8 represent the chances that dissimilar genotypes should occur in the members of pairs of fraternal twins or full sibs. The formulæ apply to genetic loci with $1,2,3,4$ and $n$ co-dominant alleles having frequencies of $a, b, c, d$ and $p$ 
respectively. A general formula for sib-sib frequencies for a system of two allelomorphs and the extension of this in the evaluation of ten human blood antigen systems have been described (Fisher, 195I; Smith and Penrose, 1955). The general formula for $n$ co-dominant allelomorphs has not appeared elsewhere.

It may be assumed that most extensive pedigree registers contain a small proportion of unknown erroneous entries and it is occasionally

\section{TABLE 9}

The proportion of possible pedigree errors which would be revealed by comparing the genotypes of putative relatives

\begin{tabular}{|c|l|}
\hline$P_{1}$ & 0 \\
$P_{2}$ & $a(1-a)^{2}$ \\
& $+b(1-b)^{2}$ \\
& $-(a b)^{2}[4-3(a+b)]$ \\
$P_{3}$ & $a(1-a)^{2}$ \\
& $+b(1-b)^{2}$ \\
& $+c(1-c)^{2}$ \\
& $-(a b)^{2}[4-3(a+b)]$ \\
& $-(a c)^{2}[4-3(a+c)]$ \\
& $-(b c)^{2}[4-3(b+c)]$ \\
$P_{4}$ & $a(1-a)^{2}$ \\
& $+b(1-b)^{2}$ \\
& $+c(1-c)^{2}$ \\
& $+d(1-d)^{2}$ \\
& $-(a b)^{2}[4-3(a+b)]$ \\
& $-(a c)^{2}[4-3(a+c)]$ \\
& $-(b c)^{2}[4-3(b+c)]$ \\
& $-(a d) 2[4-3(a+d)]$ \\
& $-(b d)^{2}[4-3(b+d)]$ \\
$P_{n}$ & $-(c d)^{2}[4-3(c+d)]$ \\
& $\Sigma p(1-p)^{2}-\Sigma\left(p_{i} p_{j}\right)^{2}\left[4-3\left(p_{i}+p_{j}\right)\right]$ \\
&
\end{tabular}

possible to trace such errors and to assess the error rates. Any routine testing programme recognising known genetic properties in putative lineages may reveal a certain proportion of an unknown total number of erroneous parentages. The four formulæ in table 9 may be used to calculate that proportion of this total which would be detected by using genetic systems controlled by 2, 3,4 and $n$ co-dominant allelomorphic genes occurring at given frequencies. The formulæ are applicable to disputed maternity and to disputed paternity. A formula equivalent to the $P_{3}$ formula in table 9 was presented previously (Gahne, 1961) but the general formula for $n$ co-dominant allelomorphs has not appeared elsewhere.

Table Io is concerned with three kinds of practical problems, each involving the identification of cattle. It is assumed that the breeds and the transferrin types only are given. Three probability values are shown opposite each breed. The gene frequency data essential 
for the calculation of probabilities shown in table 20 were extracted from the author's unpublished records.

The first column of probabilities in table ro indicates the proportion of dissimilar transferrin genotypes expected in the members of random pairs of cattle. Given the relevant parameters for a population, the chance of identifying an animal can be stated as the frequency of its recognisable genetic characteristics, compared with the inverse of the number of animals similarly tested. Friesian genes $\mathrm{Tf}^{\mathrm{a}}$, $\mathrm{Tf}^{\mathrm{d}}$,

TABLE 10

Examples of probability values limiting three possible applications of the cattle transferrin variants

\begin{tabular}{|c|c|c|c|}
\hline \multirow{2}{*}{ Cattle breed } & \multicolumn{2}{|c|}{$\begin{array}{l}\text { The proportion of pairs with members } \\
\text { showing dissimilar transferrin types }\end{array}$} & \multirow{2}{*}{$\begin{array}{l}\text { The proportion of } \\
\text { the total erroneous } \\
\text { pedigrees which } \\
\text { would be exposed } \\
\text { using transferrin } \\
\text { types only }\end{array}$} \\
\hline & $\begin{array}{l}\text { Unrelated } \\
\text { pairs }\end{array}$ & $\begin{array}{l}\text { Dizygotic twins } \\
\text { and full sib pairs }\end{array}$ & \\
\hline Aberdeen Angus & $0 \cdot 696$ & 0.421 & 0.279 \\
\hline Ayrshire & $0.86 t$ & 0.569 & $0.45 \mathrm{I}$ \\
\hline British Friesian . & 0.828 & 0.540 & 0.427 \\
\hline Charollais : & 0.720 & 0.460 & 0.275 \\
\hline Dairy Shorthorn & 0.766 & 0.482 & 0.325 \\
\hline Devon . . & $0 \cdot 767$ & 0.497 & 0.320 \\
\hline Galloway . & 0.773 & 0.499 & 0.326 \\
\hline Guernsey . & 0.790 & 0.515 & 0.343 \\
\hline Hereford. & 0.816 & 0.537 & 0.336 \\
\hline Jersey & 0.673 & 0.406 & 0.246 \\
\hline Lincoln Red & $\begin{array}{l}0.717 \\
0.820\end{array}$ & $0 \cdot 445$ & 0.277 \\
\hline $\begin{array}{l}\text { N. Daury Shorthorn } \\
\text { Red Dane. }\end{array}$ & $\begin{array}{l}0.839 \\
0.746\end{array}$ & $\begin{array}{l}0.550 \\
0.466\end{array}$ & $\begin{array}{l}0.418 \\
0.302\end{array}$ \\
\hline Red Poll . & 0.814 & & 0.377 \\
\hline South Devon & 0.762 & 0.484 & 0.316 \\
\hline 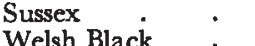 & 0.770 & 0.507 & 0.332 \\
\hline Welsh Black & 0.660 & 0.426 & 0.220 \\
\hline
\end{tabular}

$\mathrm{Tf}^{\mathrm{d} 2}$ and $\mathrm{Tf} \mathrm{e}^{\mathrm{e}}$ with frequencies of $0.47,0.22,0.26$ and 0.05 , are the basis of the following example which considers transferrin types only. Ten discontinuous transferrin types are known in Friesian sera. The frequency of the commonest type, Tf-a2d2, is 0.24 , and it appears in practically all herds, but 0.003 is the frequency of the rarest type, Tf-e, which appears in very few herds. If the problem were to discriminate the members of random pairs of Friesian cattle, pairs in which both members were Tf-a2d2 would have a frequency of 0.059 , and pairs of Tf-e would be practically non-existent at 0.000009 . The sum of those two frequencies and the frequencies of the remaining eight types of pairs containing ambiguous members, is 0.172 . This leaves 0.828 as the chance that two unrelated Friesians should have different transferrins, table 10. Similar probabilities ranging from 0.66 to 0.86 were obtained for other breeds of cattle in Britain, shown in the first column of table 10 . For example, if it were thought necessary 
the recorded transferrin types of new-born calves could be used subsequently to distinguish about 0.76 of changeling pairs.

The second column in table Io gives the changes of dissimilar transferrin genotypes occurring in the members of fraternal twins in breeds. Table 8 formulæ were used. Twin diagnoses are concerned also with the recognition of ambiguous or dissimilar types in pair members, but the similarity of dizygotic sib pair members are enhanced to a predictable extent by their genetic relationship, and may be influenced to a variable extent by non-genetic twinship effects, usually exerted before birth, e.g. blood cell chimeras. No non-genetic twinship effect is known to influence the serum proteins of twins.

Those genetic systems which are most likely to distinguish dizygotic twins are also the most informative when inferring monozygosity. Monozygosity cannot be established conclusively, but it may be inferred with increasing confidence as evidence accumulates supporting the genetic similarity of pair members, particularly if their similar genes occur in independent linkage groups.

The proportions of possible erroneous pedigrees which would be detected using transferrin data, were calculated for several breeds. See table 9 formulæ and the last column in table 10.

The probability of revealing erroneous pedigrees by using the cattle transferrin genotypes were comparable with similar probabilities using the elaborate $\mathrm{Rh}$ system in man (Race and Sanger, 1962) or the $B$ system in cattle and higher than those obtained using the cattle erythrocyte antigen systems A, FV, J, L, M, SU or Z (Rendel, I958).

\section{DISCUSSION}

The variation in the cattle transferrins suggest the following alternative interpretations of their inheritance.

(I) Each stained band within each pattern could be produced by one of a set of four genes in close linkage, or

(2) the group of four bands in each inherited pattern could be a set of protein polymers determined by one allelomorphic gene.

Either of those interpretations were applicable to the earlier descriptions of cattle transferrin inheritance, but the more recent findings tend to favour the second interpretation.

Six distinct classes of cattle sera were recognised in the earlier electrophoretic resolution of protein band differences among cattle transferrins. The six were made up of three with three, two with fours and one with five bands. The bands appeared to belong to five regions called A, B, C, D and E. The six types showed bands in regions $\mathrm{ABC}, \mathrm{BCD}, \mathrm{CDE}, \mathrm{ABCD}, \mathrm{BCDE}$ and ABCDE. Pairs of the former three patterns were recognised as the inherited basis of the latter patterns containing four and five bands. A total of eight basic patterns are now recognised giving $(8+7+6+5+4+3+2+1)=36$ possible phenotypes, of which twenty have been observed to date. The 
increased electrophoretic resolution now obtainable shows that each of the eight basic patterns contains four, not three bands, and the bands no longer appear to fit into a limited number of regions. Most, or possibly all of the bands have a distinct electrophoretic mobility, so that there is no apparent way in which a replica of any one of the eight basic patterns could be constructed by combining the band components of the others. The available evidence suggests that the number of cattle transferrin variants may be made up of $8 \times 4=3^{2}$ individual bands. As far as is known, the basic patterns are always inherited as units. There is no evidence for genetic recombination.

Because all of the available genetic data for transferrins points to series of co-dominant allelomorphic genes, the transferrin genotypes can be read directly from the test results without examining the lineages of the animals tested. Genes at the Tf locus have been postulated in many species to interpret observed transferrin variation, anticipating the genetic data which may accumulate later. The opportunities to collect genctic data are usually restricted to domesticated forms, and range from the frequent matings of animals with some common polymorphs, to those matings which do not normally occur between animals carrying rare mutants in different isolated populations.

It may be implied that homologous series of allelomorphic genes, at the Tf locus control the transferrins in all species. Evidence supporting this homology is as yet limited to an observation on a single hybrid dove (Mueller et al., r 962 ). The transferrins of mules and other hybrids have not been reported.

Compared with certain blood antigen systems in animals, the protein systems generally have their genotypes completely exposed by suitable electrophoretic methods, and their genotypes can be read directly after their apparent mode of inheritance has been confirmed by using a convincing amount of critical family data. This recognition of co-dominant genotypes simplifies all kinds of genetic exercises from describing the effect of a single gene to arranging genes in chromosome maps.

An increasing number of polymorphisms in blood, milk and egg proteins are being shown to have genetic interpretations similar to that applied to the transferrins. It is probable that many of the new systems will play an increasing role in those investigations in which red cell antigens have been used mainly. The relative usefulness of known genetic systems in particular problems can be assessed, provided the gene frequencies are known for the material in question.

In the routine application of genetic grouping methods to problems concerned with the identification of domestic animals, the systems of genes with the greatest practical use, would form manageable series of up to about ten co-dominant genes, and such systems would be most useful if none of the several allelomorphs were unusually rare and unfamiliar. The cattle transferrin system has many of the 
attributes of an ideally useful marker system. It is known that it can be usefully applied in all of the sixty cattle breeds tested to date because all show transferrin polymorphism. Any domestic species showing similar systems of co-dominant allelomorphs in each of several chromosomes would leave a very small fraction of insoluble identification problems.

By analogy with the findings in domestic forms, similar methods may continue to reveal similar variants in natural forms. It is probable that new polymorphic systems will be found in those species in which genetical information may help towards an enlightened approach to numerical control. The fishing industry offers many important examples (Cushing, r 964). Genes for protein varieties may be used to follow genetic changes over generations in moving populations, and to demonstrate the degrees of isolation or interrelation of populations currently regarded as ecotypes.

The general formulæ developed here and applied to cattle transferrins, are for co-dominant allelomorphic series in general, and can be modified to compass all conventional genetic systems used in the most familiar examples of identification problems using genetic groups in diploid organisms.

\section{SUMMARY}

1. Improvements in the electrophoretic resolution of cattle transferrins reveal an increasing number of phenotypes.

2. A revised notation is proposed for the known, and postulated phenotypes. The notation also described transferrin patterns, genes and genotypes in a system based on the eight reported co-dominant allelomorphic genes at the cattle Tf locus.

3. Seven new transferrin phenotypes appeared in British cattle. They are named Tf-dI, Tf-d2, Tf-a2di, Tf-a2d2, Tf-die, Tf-d2e and $T f-d_{1} d_{2}$. This paper gives the first published descriptions of those types and the first information on the inheritance of the two new genes Tf $d 1$ and $\mathrm{Tf} \mathrm{d}^{2}$.

4. The family data which consisted of a large proportion of the many possible matings, supported the extension of the existing allelomorphic series at the cattle Tf locus.

5. The transferrins in monozygotic and dizygotic twin cattle also supported the multiple allelomorphic interpretation. The twin transferrin data was interpreted without claiming or assuming transferrin chimeras.

6. The extended series of co-dominant genes at the cattle $\mathrm{Tf}$ locus may be usefully applied to the practical problems of identifying individuals, testing parentages and diagnosing twinship zygosity.

7. Some general formulæ describing the use of series of $n$ codominant allelomorphic genes have wide practical applications.

Acknowledgments. - The author thanks Annie B. Small who gave welcome technical assistance and $\mathrm{Mr} \mathrm{C}$. $\mathrm{H}$. C. Mathews of the Edinburgh University Electrical 
Engineering Department, who constructed a regulated power supply. Colleagues in A.B.R.O. gave helpful discussion and criticism. In particular, Dr J. G. Hall gave invaluable advice and encouragement.

\section{REFERENCES}

Ashton, G. c. 1957. Zone electrophoresis of mammalian sera in starch gels. Nature, Lond., 179, 824-825.

Ashton, G. c. 1957. Serum protein differences in cattle by starch gel electrophoresis. Nature, Lond., I80, I97-199.

AshtoN, G. C. 1958. (a) Genetics of $\beta$-globulin polymorphism in British cattle. Nature, Lond., 182, 370-372.

Ashron, a. c. 1958. (b) Serum protein variation in horses. Nature, Lond, I82, I029-1030.

AshtoN, G. C. 1959. (a) $\beta$-globulin polymorphism and early fotal mortability in cattle. Nature, Lond., $183,404-405$.

Ashton, G. c. I959. (b) $\beta$-globulin alleles in some Zebu cattle. Nature, Lond., 184 , II $35^{-1}$ I 36 .

Ashton, G. c. I96o. Thread protein and $\beta$-globulin polymorphism in the serum proteins of pigs. Nature, Lond., 186, $991-992$.

Ashton, G. C., AND FERguson, K. A. 1963. Serum transferrins in Merino sheep. Genetic Res. Camb., 4, 240-247.

AShton, G. G., AND LAMPKIN, G. H. 1965. Serum albumin and transferrin polymorphism in East African cattle. Nature, Lond., 205, 209-2 Io.

Ashton, G. C., AND MCDOUGAL, E. I. 1958. $\beta$-globulin polymorphism in cattle, sheep and goats. Nature, Lond., $182,945$.

BECKMAN, L. 1963. Serum protein variation in primates. Symposia of the Zoological Society of London number 1o. The Primates, pp. 25I-26I.

BOоTH, P. B., PLAUT, G., JAMES, J. D., IKIN, E. W., MOORES, P., SANGER, R., AND RACE, R. R. 1957. Blood chimerism in a pair of twins. British Medical Journal, $I$, $1456-1458$.

BRAEND, M. 1962. Studies on blood and serum groups in the elk (Alces alces). Blood groups in infrahuman species. Ann. N.Y. Acad. Sci. Vol. 97. Ant I, 296-305.

BRAEND, M. 1964. Polymorphism in the serum proteins of the reindeer. Nature Lond., $203,674$.

BRUMMERSTEDT-HANSEN, E., MOUSTGAARd, J., OG møller, iB. 1962. Serumtypestemmelse inden for danske kvaegracer 1959-1962. Den kongelige Veterinaer-og Landbokøjskole, Institut for Sterilitetsforskning Aarsberetning I962.

cohen, B. L. 1960. Genetics of mouse transferrins. Genet. Res. (Camb.), 143 I.

COHEN, B. L., AND SHREFFLER, D. H. I961. A revised nomenclature for the mouse transferrin locus. Genet. Res. (Camb.), 2, 306-308.

COOPER, D., AND SHARMAN, G. B. 1964. Transferrin variation in kangaroos. Nature, Lond., 203, I094.

cushing, J. E. 1964. The blood groups of marine animals. Adv. Mar. Biol., 2, 85-13I.

Datta, s. P., and stone, w. н. 1963 . Transferrins in cattle twins. Proc. Soc. Exp. Biol. and Med. N.Y. 1063, II3, 756-759.

FISHER, R. A. 1951. Standard calculations for evaluating a blood group system. Heredity, 5, 95-102.

GAHNE, Bo. 1961. Studies of transferrins in serum and milk of Swedish cattle. Anim. Prod., 3, I35-145.

GALL, G. A. E., AND BERG, R. T. 1964. Studies of the inheritance of bovine serum transferrins. Anim. Prod., 6, 107-I 18.

HAll, J. G. 1963. Cattle Blood Groups, Man and Cattle. A symposium, Royal Anthropological Society of Great Britain and Ireland, pp. 25-33. 


\section{Plate I}

The transferrin variants in the blood sera of domestic cattle in Britain

Plate I demonstrates the ten transferrin variants found in the domestic cattle of Britain. This photograph shows slices from the anodic side of a slab of starch gel in which the proteins in selected cattle sera had been separated by zone electrophoresis. The transferrin patterns appear as stained protein bands just behind the broad continuous albumen band. The samples were arranged in six sets of three. A different heterozygote was placed in the centre of each trio, and each heterozygote was flanked by its two appropriate parental homozygotes. The six heterozygotes appear as the second, fifth, eighth, eleventh, fourteenth and seventeenth sera. 


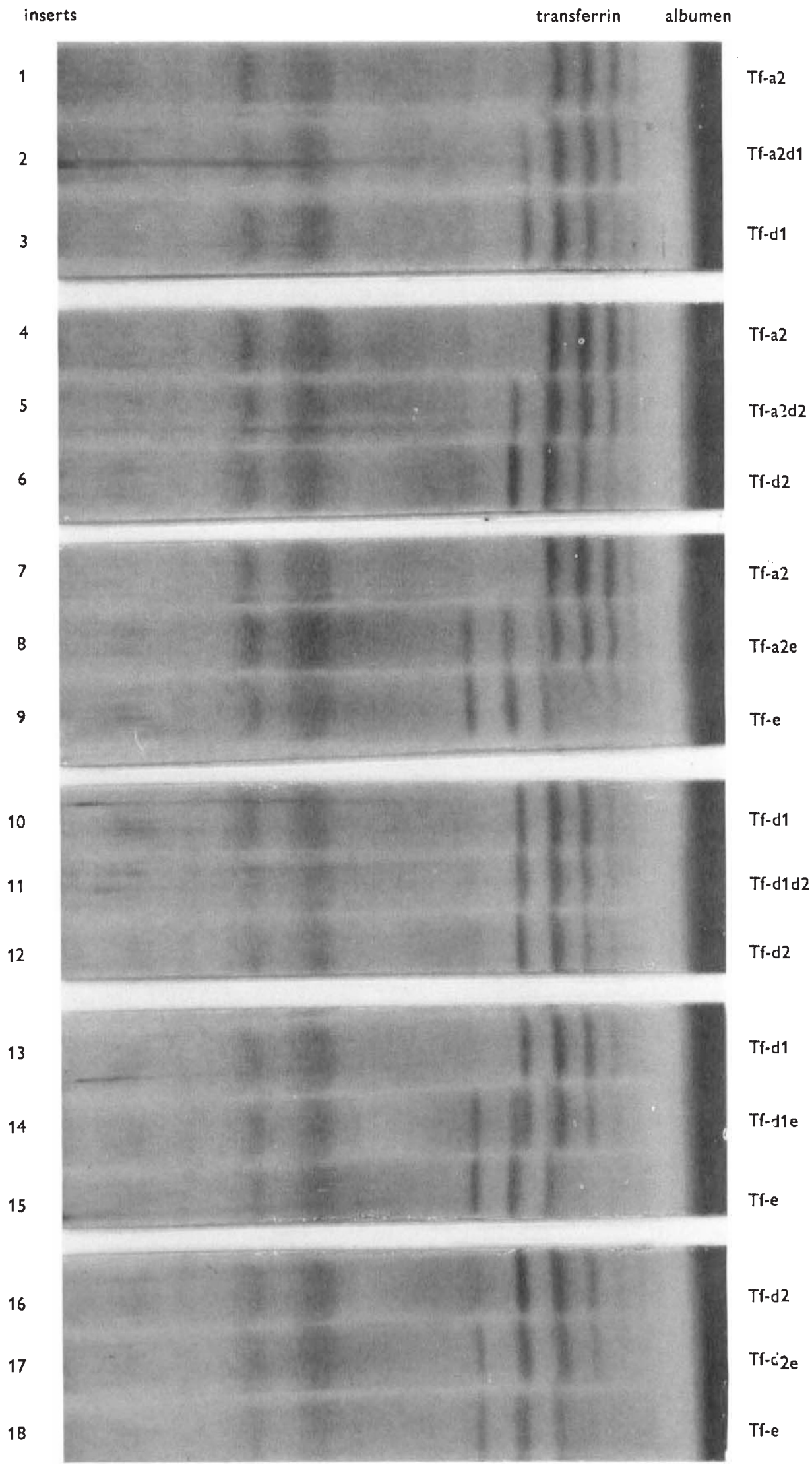


hARRIS, H., ROLSON, E. B., AND SINISCALCO, M. I958. $\beta$-globulin variants in man. Nature, Lond., 182, 452.

hickman, c. G., AND smithies, o. 1957. (Abstract) Proc. Gen. Soc. of Canada, 2, 39. KRISTJANSSON, F. K. I962. Unpublished report. Recent research in serum protein polymorphism of livestock, 8th Animal Blood Group Conference in Europe, Ljubljana.

Millson, G. C., AND PATtison, 1. H. 1961. $\beta$-globulin polymorphism in goats. Vet. Rec., 73, 256.

MUELLER, J. O., SMITHIES, O., AND IRWIN, M. R. 1962. Transferrin variation in Columbide. Genetics, 47, 1385-1 392 .

OSTERHOFF, D. R. I964. Resent research on biochemical polymorphism in livestock. J. S. Afr. Vet. Med. Ass., 35 (3), 363-38o.

OWEN, R. D. I945. Immunogenetic consequences of vascular anastomoses between bovine twins. Science, 102, 400-40I.

PARKER, W. C., AND BEARN, A. G. Ig6I. Haptoglobin and transferrin variation in humans and primates. Ann. Hum. Genet. Bol. 25, Part 3, 227-240.

PouLIK, M. D. 1957. Starch gel electrophoresis in a discontinuous system of buffers. Nature, 180 , I477-1479.

RACE, R. R., AND SANGER, RUTH. 1962. Blood Groups in Man. 4th edition. Blackwell Scientific Publication Oxford.

RENDEL, J. 1958. Studies of cattle blood groups. II. Parentage tests. Acta Agr. Scand., 8, 131-16r.

ShREFfler, D. C. 1960. Genetic control of serum transferrin types in mice. Proc. Nat. Acad. Sci., 46, г 378.

SMITH, SHEILA M., AND PENROSe, L. s. 1955. Monozygotic and dizygotic twin diagnosis. Ann. Hum. Genet., 19, 273-289.

sMithIES, O. 1955. Zone electrophoresis in starch gels. Biochem. F., 6I, 629 .

SMITHIES, O., AND HICKMAN, C. G. 1958. Inherited variations in the serum proteins, of cattle. Genetics, 43, 374-385. 